Information Management and Business Review

Vol. 3, No. 4, pp. 222-227, Oct 2011 (ISSN 2220-3796)

\title{
The Influence of Customer Orientation on Customer Relationship in Telecom Services
}

\author{
*Junaid-ul-haq, Awais Ijaz, Saqib Mehmood \\ International Islamic University, Islamabad, Pakistan \\ *junaidulhaq041@gmail.com
}

\begin{abstract}
In this study, an effort has been made to disclose the influence of customer orientation on customer retention. It has also revealed that customer orientation influences on customer satisfaction and customer trust and their ultimate effect on customer Retention. Primary data was collected through questionnaire survey.290 questionnaires were distributed out of which 219 were received and supposed for analysis purpose, $75.51 \%$ which is considered as a serious response rate of our respondents. Customer orientation has positive effect on customer satisfaction as well as on customer trust, which shows significant relationship of customer orientation on customer satisfaction and customer trust. Moreover, satisfaction and trust of customer has effect on customer retention. Satisfaction of customer has negative effect due to one or more reason, whereas, customer trust has positive and significant effect on customer retention. Customer orientated organizations earn more profit and can control customer retention. Findings of this study can also be used to control the customer retention. While customer orientation is under discussion then it has two major factors i.e. customer satisfaction and customer trust, organizations should more focus on these factors. Sometime when customer retention takes place even focusing these factors then current competitor's strategies can also be kept in mind. This study is done in a developing country where there is a very tough competition among service providers to enhance their market share. The focus of this research is to control the switching customer, which is the one of the important problems facing by the service providers.
\end{abstract}

Keywords: Customer Orientation, Customer Satisfaction, Customer Trust, Customer Retention

\section{Introduction}

Telecom sector is one of the most profits generating sector in Pakistan. Increasing competition in telecom sector favors the customers; meanwhile it also creates the problem for organization to control the retention of customers. According to Pakistan Telecom Authority (PTA, 2010), number of subscribers has not increased so much but higher rate of retention took place this year. This sector has generated multifarious employment opportunity at every level for Pakistani people. While economy is experiencing flight of capital. It is the only sector attracting foreign direct investment (FDI). During last five years more than 6.3 Billion US\$ has been invested in telecom sector, which is an encouraging response by investors in telecomm industry (Anonymous, 2010). Increasing competition in service provider, offers comparatively less rates and more attractive packages. The cell phone density with an increase of $2.18 \%$ reached at $60.40 \%$ (Anonymous, 2010). At present healthy competition prevails in mobile telecom field.

In background of service selling, most of the times researchers found that focus were always to follow the customer orientation approach. Wray et al. (1994) and Hennig-Thurau (2004) explains that customer relationship is most of the time positively affected by the customer orientation approach. Moreover, behavior of employee, while providing or selling services gives the output in the form of orientation that might be customer orientation and try to develop strong customer-seller relationship, which is not studied empirically in our scenario. Customer sticks to the products and services of the firms that provides higher value and maximizes their level of satisfaction. This increase in level of satisfaction increases customer loyalty that ultimately ends in customer retention (fornell, 1992).

\section{Literature Review}

Customer orientation at micro level depicts in the behavior of individual salesperson and customer service representative. Customer-oriented sales person make their customer aware of what their needs and wants are and how that can be satisfied with a given set of products or services. Customer oriented sales persons 
avoid all the efforts which may cause annoyance of dissatisfaction of the customer (Michaels and Day, 1985). When goods are produced with the aim to satisfy customers' needs and wants, is termed as customer orientation. Customer oriented companies train their employees to help their customers in purchase decisions by understanding their needs and wants and selecting best possible solution, which may maximize their level of satisfaction and trust on the company (Saxe and Weitz 1982). $H_{1}$ Customer orientation will have positive influence on customer satisfaction.

To increase business profitability sales persons would not risk the customer's satisfaction and would not use short sighted selling tactics to increase short term business profitability (Saxe and Weitz, 1982). According to Anderson et al., (1997) customer satisfaction is evaluation of firm's services or products to adequately fulfilling customer need. Customer satisfaction result in more profits for both retailer and manufacturer (Chu and Desai, 1995). In services sector customer have high level of segmentation which affect the satisfaction in positive or negative way, so while doing segmentation do analyze its effect on customer satisfaction (Diaz martin et al., 2000). Services having higher level of customer satisfaction and thus consequently provides with higher ROI than that of manufacturing sector (Anderson et al., 1997). Higher is the customer satisfaction, higher is profitability. Customer wants satisfaction that is possible only when company adopts the philosophy of customer orientation.

According to fornell (1992), companies with higher customer base have lower customer satisfaction. According to their research findings, there is a strong relationship of customer retention with customer satisfaction. With the help of satisfaction and commitment, companies can have customer loyalty, and all these variables have very strong effect on customer retention. $\mathrm{H}_{2}$ Customer satisfaction will have positive influence on customer retention. Customer relationship quality improves parallel with the approach termed as customer orientation and customer orientation (especially in service sector) influences the trust of the customer (Huang, 2007). Moreover, Positive association of trust and customer orientation has proved (Huang and Dastmalchian, 2006) in their circumstances. However, trust has also significant and positive effect on the retention of the customers of service providers (Min-Hsin Huang, 2007). $H_{3}$ Customer's trust will have positive influence on customer retention.

If service provider posses customer orientation approach than customer would express higher level of trust on it. Product availability and customer care has a positive effect on trust that customers have on a service provider (Bauer et al., 2001). Customers prefer to develop their long-term relations with only those firms that provide higher customer dedication (Crosby et al., 1990). Future sales heavily depend on customer satisfaction and trust. Researchers like Fornell et al. (1996) have proved the notion that customer satisfaction has positive effect on customer loyalty, furthermore satisfaction and loyalty result in customer retention. In an era of cut throat competition it has become highly unavoidable to dissatisfy an existing customer. Cost to attract a new customer is far higher than retaining an existing customer. Now it has become a paramount consideration for the company to go for long-term relationship with customer for its survival and growth (Berry, 1995; Hennig-Thurau, 2004). If a customer uses a product or service and this service meets his expectations than he creates some inclination towards service provider, next time he repurchases and have the same level of expectation as experienced in previous purchase (Crosby et al., 1990). Customer makes repurchase decision because of prior consumption, if customer is satisfied with prior experience of the service or product he will go for the same product or service.

Service provider performance is not the only reason for customer retention. Other factors such as customer commitment with the service provider and trust placed on the service providers play important role in customer retention (Garbarino and Johnson, 1999). Repurchase is one of most important factor for customer loyalty. If the customer is satisfied with some service, he would never like the risk to switch the service and thus will result in positive customer retention (Sirdeshmukh et al., 2002). Huang (2007) argues that customer orientation approach increases indirectly with the customer retention. $\mathrm{H}_{4}$ Customer orientation will have positive influence on customer trust. 


\section{Methodology}

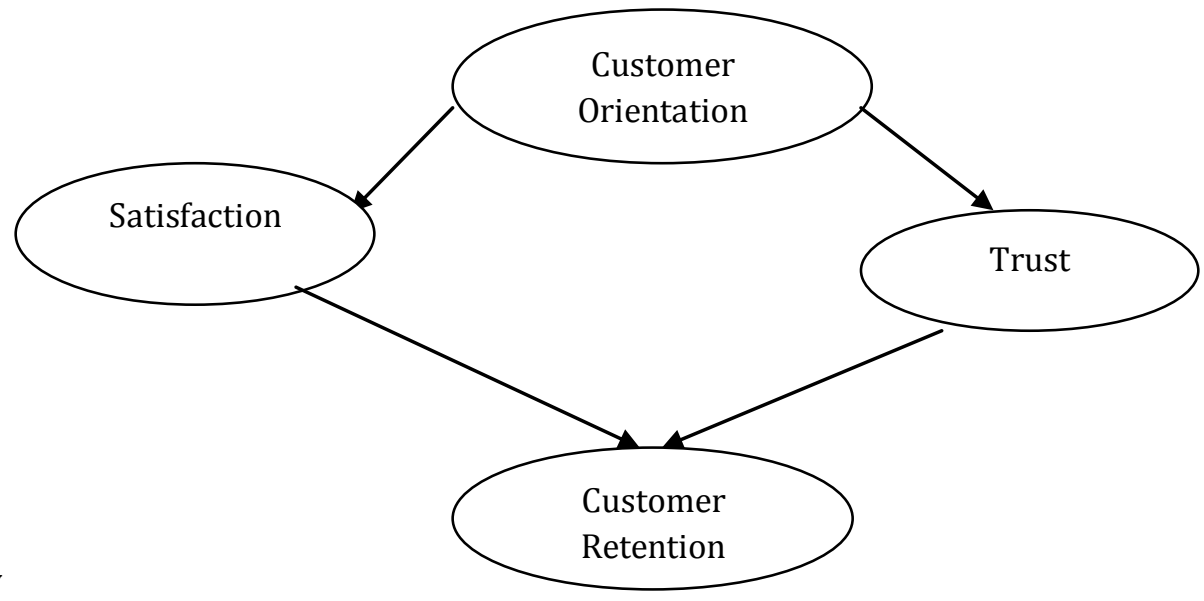

A conceptual framework is proposed that consider customer retention as outcome of CO (customer orientation) approach. The idea of this model has derived by SOCO model, (used by saxe and weitz) and then Min-Hsin huang. Four telecom operators are selected from telecom sector of Pakistan to test the framework (Anonymous, 2010). To test the theoretical framework, sample is drawn from cellular service providers from telecom sector. A questionnaire was developed using a multiple item scale to measure the constructs of model presented in the earlier study. All the items are measured using a five point likert scale ranging from strongly disagree to strongly agree.

Random sampling technique was used to collect the data because every individual have equal chances to become the respondent. Customers of cell phone industry using different service providers were our respondents. Responses were gathered from students and professionals in their leisure time like students were mostly approached when they were free from classes and professionals in their break time. Common thing in both respondents that they were prepaid customers of service provider. Prepaid customers are always considered as a short-term customer, no long term binding with service provider. Therefore, service providers have to retain this nature of customers. Total 290 questionnaires were distributed among different service users. Out of which 245 were received with response rate of $84.48 \%$. Out of total questionnaire received, 219 questionnaires were in the position that there results can be demonstrated in this research study. Response rate of serious respondents was $75.51 \%$.

\section{Results}

Validity: Joreskog and Sorbon (1993) describe that for rose of uni-dimensional, when GFI is 0.90 or more. Goodness to fit Index; GFI of all variables are near to 0.90 which shows the validity of our data and GFI of our model proposed for hypothesis testing is 0.833 . Bentler-Bonett, Normed Fit Index (NFI) used to examine the Convergent validity (Bentler-Bonett, 1990). NFI is 0.801 of our proposed model, which is considered worthwhile.

Index for fit of the Model: The value of Chi-square $\left(\chi^{2}\right)$ is 174.8 and degree of freedom (df) is 24 .

\begin{tabular}{ll} 
Reliability Test & \\
\hline Variables & Cronbach's Alpha ( $\boldsymbol{\alpha})$ \\
\hline Customer Orientation & .703 \\
Satisfaction & .761 \\
Trust & .742 \\
Customer Retention & .732 \\
\hline
\end{tabular}




\section{Structural Equation modeling (SEM) Technique}

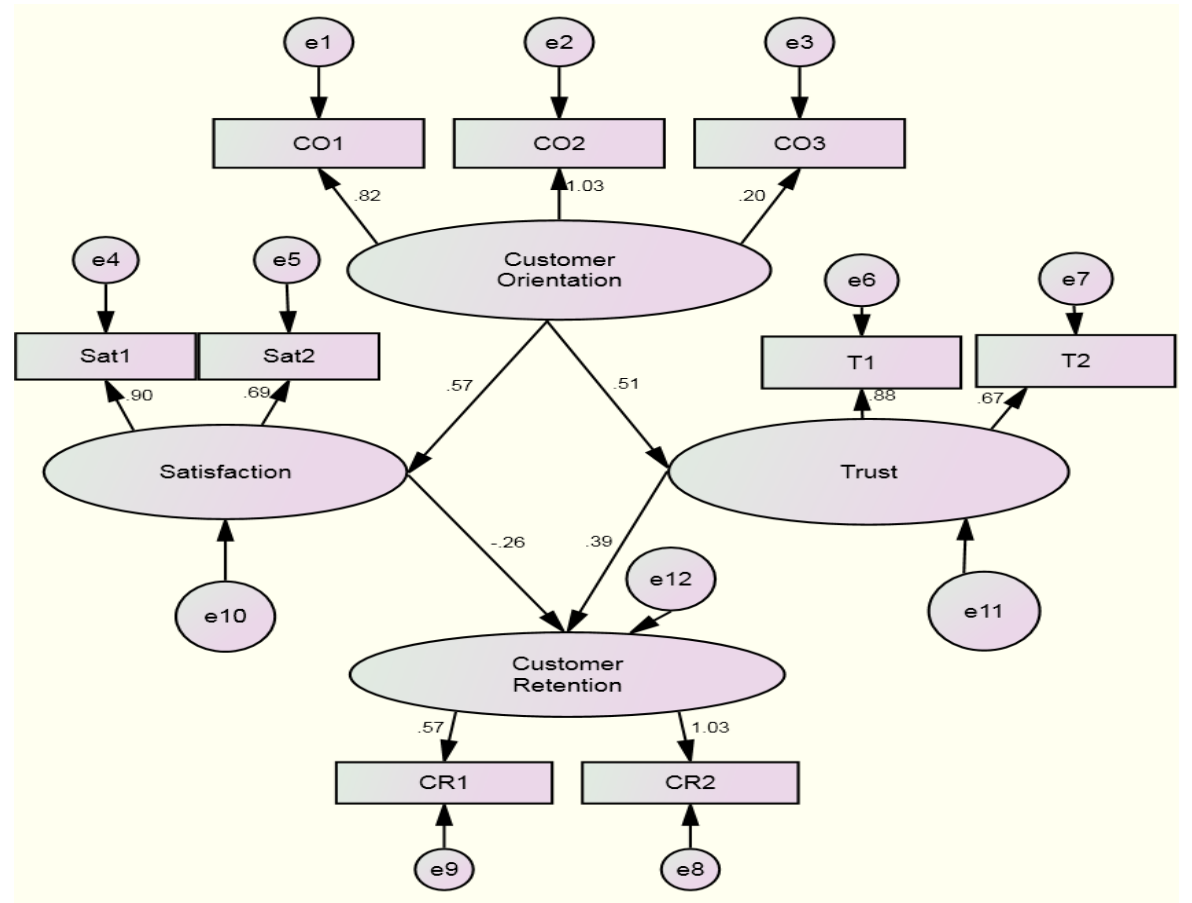

Some formerly proposed items deleted in order to achieve the construct reliability. This increased the scale reliability instead of decreasing scale reliability. According to Chin et al., for the identification of any scale two-item scale is valid (2008).

\section{Hypotheses testing based on Regression weights}

\begin{tabular}{lcrc}
\hline Path & Estimate & P-value & Label \\
\hline Satisfaction <--- Customer Orientation & .572 & 0.00 & Accepted \\
Trust <--- Customer Orientation & .515 & 0.00 & Accepted \\
Customer Retention <--- Satisfaction & -.258 & .000 & Accepted \\
Customer Retention <--- Trust & .391 & .000 & Accepted \\
GFI $=.862$ & & & \\
AGFI $=.742$ & & & \\
CFI $=.826$ & & & \\
RMSEA $=.170$ & & &
\end{tabular}

Notes: GFI = Goodness of Fit Index; AGFI = Adjusted Goodness of Fit Index; CFI = Comparative Fit Index; RMSEA = Root Mean Square Error Approximation

Test of Hypothesis: The Structural Equation modeling Technique tested projected relationships among variables. Results are enclosed in above table. The beta value of $\mathrm{H}_{1}$ is .572 , which shows the positive association between customer orientation and satisfaction and exposes that improvement in customer orientation of service provider should result in the improvement of customer satisfaction about their service providers. Its P-value is less than 0.05 , so it is accepted. $\mathrm{In}_{2}$, customer orientation has considerable effect on the trust, which further proves form beta value that is .515. It reveals that as the customer orientation about service provider enhances at the same time trust of customer increases with the same ratio. It is accepted because its $P$ value is less than 0.05 . Satisfaction apparently affects customer retention, analysis shows beta value is -0.258 . Satisfaction of customers has negative as well as insignificant effect on customer retention; it is accepted because its $\mathrm{P}$-value is also lesser than 0.05. Hypothesis $\mathrm{H}_{4}$ between customer trust and customer 
retention is also accepted because its $\mathrm{P}$ - value is not more than $0.05(\mathrm{P}>0.05)$. It explains us that customer trust has also insignificant effect on the customer retention; moreover, expansion of customer trust causes the expansion of customer retention, which is ultimate objective of any organization, it additionally proves from the beta value, which is .391 .

Discussion: In this study, three relationships have positive relationship. Customer orientation has positive effect on satisfaction, trust and commitment of the customers of service provider. It shows that if the companies are more customers orientated; mean that prefer customer preferences; then customers will be more satisfied and customer will have more trust on the service provider, which will make the customer retained to that service provider. Similarly, trust has positive effect on customer retention, which exposes that to make the customer loyal, and to stop his/her switching service provider should fulfill the commitments of customers, which result in the form of the trust of the customer on the service provider. It will make the loyal and insist to re-purchase and to recommend others.

Limitations: In this research, primary data was gathered from all service providers serving in Pakistan but only from some cities of one Province, which can represent its one province. Every service provider has prepaid as well as post-paid customers; this research was entirely on pre-paid customers. In addition, students use the pre-paid services, so in our respondents there was a great junk of student customers.

Future Research: Pakistan is swiftly and lucratively moving in telecom sector, which contributes towards economy positively. Organization introduces new packages in competition, which also favors to customers, to enhance the barriers in front of switching customers, which sometimes not work effectively. Therefore, future researches can be done on individual organization and in finding more factors of switching customers.

\section{References}

Pakistan Telecommunication Authority (2010). Annual Report 2009-10 from http://www.Pta.Gov.Pk/annualreports/annrep10 (26-32).

Anderson, W. E., Fornell, C. \& Roland T. R. (1997). Customer Satisfaction, Productivity, and Profitability: Differences Between Goods and Services. Marketing Science, 16(2), 129-145.

Bauer, H. H., Grether, M. \& Leach, M. (2001). Building customer relations over the Internet. Industrial Marketing Management, 31, 155-163.

Bentler, P. M. \& Bonett, D. G. (1990). Comparative fit indices in structural models. Psychological Bulletin, 107(2), 238-46.

Berry, L. L. (1995). Relationship marketing of services-growing interest, emerging perspectives. Journal of the Academy of Marketing Science, 23(4), 236-45.

Chin, W., Peterson, R. \& Brown, S. (2008). Structural equation modeling in marketing: Some practical reminders. Journal of Marketing Theory and Practice, 16(4), 287-98.

Chu, W. \& Desai, S. P. (1995). Channel Coordination Mechanisms for Customer Satisfaction. Marketing Science, 14(4), 343-359.

Crosby, L. A., Evans, K. A. \& Cowles, D. (1990). Relationship quality in services selling: an interpersonal influence perspective. Journal of Marketing, 54(3), 68-81.

Diaz, M. A., Audustin, A. \& Rodolfo, V. (2000). The use of quality expectations to segment a service market. Journal of Services marketing, 14(2), 132-146.

Fornell, C. (1992). A national customer satisfaction barometer: The Swedish experience. Journal of Marketing, $56,6-21$.

Fornell, C., Johnson, M. D., Anderson, E. W., Jaesung, C. \& Bryant, B. E. (1996). The American customer satisfaction index: nature, purpose, and findings. Journal of Marketing, 60(4), 7-18.

Garbarino, E. \& Johnson, M. S. (1999). The different roles of satisfaction, trust, and commitment in customer relationships. Journal of Marketing, 63, 70-87.

Hennig-Thurau, T. (2004). Customer orientation of service employees: its impact on customer satisfaction, commitment, and retention. International Journal of Service Industry Management, 15(5), 460-78.

Huang, M.H (2007). The influence of selling behaviors on customer relationships in financial services. International Journal of Service Industry Management, 19(4), 458-473. 
Huang, J. H. \& Dastmalchian, A. (2006). Implications of trust and distrust for organizations Role of customer orientation in a four-nation Study. Personnel Review, 35(4), 361-377.

Joreskog, K. G. \& Sorbom, D. (1993). LISREL 8: A Guide to the Program and Applications, Scientific Software International, Chicago, IL.

Michaels, R. E. \& Day, R. L. (1985). Measuring customer orientation of salespeople: a replication with industrial buyers. Journal of Marketing Research, 22, 443-446.

Saxe, R. \& Weitz, B. A. (1982). The SOCO Scale: a measure of the customer orientation of salespeople. Journal of Marketing Research, 19, 343-51.

Sirdeshmukh, D., Singh, J. \& Sabol, B. (2002). Consumer trust, value, and loyalty in relational exchanges. Journal of Marketing, 66, 15-37.

Wray, B., Palmer, A. \& Bejou, D. (1994). Using neural network analysis to evaluate buyer-seller relationships. European Journal of Marketing, 28(10), 32-48. 